\title{
Maria Borejszo
}

Uniwersytet im. Adama Mickiewicza w Poznaniu

\section{Kolory Afryki w powieści Henryka Sienkiewicza W pustyni i w puszczy. Część II: ludzie i ich wytwory ${ }^{1}$}

Kolejną dość dobrze udokumentowaną w powieści Henryka Sienkiewicza grupę realiów, którym przyporządkowano jakieś barwy, tworzą ludzie i związane z nimi przedmioty, takie jak: odzież, tkaniny, akcesoria stroju (np. nakrycia głowy, biżuteria, okulary), a także różne przedmioty będące wytworem rąk ludzkich (np. budynki, namioty). Występujący w powieści bohaterowie ze względu na pochodzenie i kolor skóry reprezentują kilka ras. Przede wszystkim są to Europejczycy (np. Polak Władysław Tarkowski i Anglik pan Rawlison oraz ich dzieci, tj. czternastoletni Staś i ośmioletnia Nel, oficerowie angielscy kapitan Glen i doktor Clary, pochodzący z Zurychu szwajcarski podróżnik Linde, Grek Kaliopuli pozostający na służbie Mahdiego w Chartumie), dalej Arabowie (np. Mahdi², Fatma, Smain, Idrys, Gebhr i Chamis, dwaj Beduini, emir Nur-el-Tadhil, kalif Abdullahi, kalif Szeryf, szeik Fatim) i Murzyni (np. Kali, Mea, Nasibu, Dinah).

Stosowane wielokrotnie w powieści określenia kolorystyczne biały $(-a)$ i czarny $(-a)$ odnoszą się w tym wypadku do koloru skóry (i pośrednio rasy) charakteryzowanych w ten sposób bohaterów, np.

Ty wiesz, że biali z Europy dotrzymują zawsze słowa. [P: 59] ${ }^{3}$

1 Pierwsza część artykułu (M. Borejszo, Kolory Afryki w powieści Henryka Sienkiewicza „W pustyni i w puszczy”. Część I: świat przyrody) ukazała się w „Poznańskich Studiach Polonistycznych. Serii Językoznawczej” (2015, vol. 22, nr 1).

2 Właściwe nazwisko arabskiego przywódcy religijnego i politycznego, nazywanego w powieści Sienkiewicza Mahdim, czyli 'odkupicielem świata' [P: 20], to Muhammad Ahmad Ibn Abd Allah al-Mahdi.

3 Wszystkie cytaty z powieści Sienkiewicza $W$ pustyni i w puszczy pochodzą z następującego wydania: Sienkiewicz 2003: 7-393 (dalej skrót: P). Wszystkie wyróżnienia w cytowanych tekstach (kursywy) pochodzą od autorki artykułu. 
Biali nie mordują niewolników [...]. [P: 344]

Bywają między czarnymi poczciwe dusze, choć w ogóle na ich wdzięczność liczyć nie można [...]. [P: 269]

Ty opowiesz Faru o Wielkim Duchu [Bogu - M.B.], który jest ojcem wszystkich biatych i czarnych ludzi, a Faru będzie cię kochał jak brata. [P: 345]

Pierwszy z wymienionych wyżej przymiotników (biały) pojawia się w powieści obok takich rzeczowników, jak: bibi [P: 305] $]^{4}$, bóstwo $[\mathrm{P}: 308$, 312], chłopiec [P: 96, 258], czarownik [P: 77], człowiek [P: 86-87, 176, 255, 263, 304, 319, 345, 350], dziecko [P: 95, 109, 112, 113, 122], istotka [P: 216], jeniec [P: 104, 139], Mzimu [P: 312], naczelnik [P: 176], naród [P: 131], pan [P: 307, 308, 312, 320, 328, 335], podróżnik [P: 288] $]^{5}$, twarz [P: 335, 358], uled [P: 91 $]^{6}$, wódz [P: 352] lub samodzielnie w funkcji rzeczownika [np. P: 59, 87, 150, 252, 258, 344, 350, 377], natomiast drugi (czarny), rzadziej stosowany, obok rzeczowników: Abisyńczyk [P: 171], chłopak [P: 165, 240, 244, 255, 262, 286], chtopiec [P: 181, 184, 227, 259, 278], człowiek [P: 328, 345], głowa [P: 286], malec [P: 259], trójka [P: 285], wojownik [P: 308], zastęp [P: 353] lub w funkcji rzeczownika [P: 149, 268]. Określenia te odnoszą się najczęściej do głównych bohaterów powieści, czyli Stasia i Nel, oraz towarzyszącej im trójki Murzynów (Kalego, Mei i Nasibu).

W powieści Sienkiewicza widać wyraźnie skontrastowanie przedstawicieli rasy białej i całego cywilizowanego świata czarnym mieszkańcom Afryki, tj. Arabom i Murzynom. Kontrast ten jest wielokrotnie w powieści przywoływany i podkreślany, nawet w kontekstach niesygnalizujących wrogiego nastawienia jednej z opisywanych stron do drugiej, np.

Nel zarzuciła mu [Kalemu - M.B.] swoje białe rączki na czarną szyję i uściskała go z całej siły. [P: 183]

Wówczas [Faru, syn Mamby, wodza plemienia Samburu - M.B.] objął swymi czarnymi dłońmi jej [Nel - M.B.] małą nóżkę i postawił ją na swojej głowie [...]. [P: 345]

4 Bibi 'dziewczynka'. Tej nazwy używa Kali, a za nim Staś, w odniesieniu do Nel [P: 166, 183 i in.].

5 W ten sposób Kali określa arabskich handlarzy kością słoniową przybyłych do jego wioski.

6 Uled 'chłopiec' [P: 68]. 
W podobnej funkcji antonimów, oznaczających dwie odmienne rasy ludzkie, różniące się m.in. kolorem skóry, funkcjonują także w powieści przymiotniki jasny i ciemny, np.

[...] a teraz stało przed nimi na grzbiecie słonia jasne bóstewko [Nel - M.B.], łagodne, słodkie i uśmiechnięte, podobne do białego ptaka i zarazem do białego kwiatu. [P: 308]

Noc była tak jasna, że z dala już ujrzał [Staś - M.B.] dwa ciemne ciała [Murzynów - M.B.] leżące koło siebie [...]. [P: 363]

Promienie księżyca rozświecały prócz namiotów białe ubrania Stasia i Nel, a wśród kęp wrzosów - ciemne, pokurczone ciała Murzynów [...]. [P: 371]

Jedynie Europejczycy (głównie kobiety i dzieci) pracujący jako niewolnicy w zdobytym przez wojska Mahdiego Omdurmanie mają, jak stwierdza narrator, twarze sczerniate z nędzy [P: 122], podobnie jak zatknięta na bambusowym kiju ścięta głowa angielskiego generała Gordona, która miała skórę tak wyschniętą, że prawie czarna [P: 126].

Różnica rasowa między zamieszkującymi Afrykę Europejczykami (biatymi) i Murzynami (czarnymi) została w powieści Sienkiewicza mocno wyeksponowana i nacechowana wartościująco ${ }^{7}$.

Niekiedy pojawiające się w powieści opisy kolorystyczne dotyczą nie tyle barwy skóry konkretnych ludzi czy ich przynależności rasowej, ile raczej ogólnego wrażenia, jakie robią ich sylwetki malujące się na różnym tle, np.

Dzieci miały już udać się na spoczynek, gdy z dala, na oświeconym przez księżyc rynku, ukazały się dwie białe postacie [Idrys i Gebhr - M.B.] zdążające ku namiotom. [P: 34]

Tymczasem Idrys i Gebhr stali wciąż jak dwie białe kolumny [...]. [P: 35] ${ }^{8}$

Czarna sylwetka Stasia zarysowała się na jaśniejszym tle otworu jaskini. [P: 81]

7 Jeden raz w powieści pojawia się także informacja o czerwonoskórych Indianach, znanych Stasiowi z literatury amerykańskiej: „Inna rzecz była czytać w Port-Saidzie o traperach amerykańskich zabijających na Dalekim Zachodzie tuzinami czerwonoskórych Indian, a inna dokonać tego osobiście [...]" [P: 169].

8 Dwaj Arabowie (Sudańczycy) ubrani byli w białe burnusy, więc ich sylwetki odbijały się w ten sposób na tle nocnego nieba. 
Nieraz też, gdy na postojach stawała przy ognisku [Nel - M.B.] nanieconym z róż jerychońskich lub cierni - różowa od płomienia i srebrna od księżyca, zarówno Sudańczycy, jak Beduini nie mogli od niej oczu oderwać [...]. [P: 92]

Słoń trąbił od rana, upominając się widocznie o posiłek, a gdy następnie ujrzał na krawędzi tę samą białą istotkę [Nel - M.B.], która nakarmiła go wczoraj, powitał ją radosnym gulgotaniem [...]. [P: 216]

[...] oto w odległości pół kilometra spostrzegł [Staś - M.B.] obszerny łan manioku, a na skraju łanu kilkanaście czarnych postaci [...]. [P: 303]

Przed namiotem zobaczył [Staś - M.B.] biała figurkę Nel [...]. [P: 367]

W obozie zabieliła mu się [Stasiowi - M.B.] postać Nel [...]. [P: 374]

[...] na grzbiecie wzniesienia pojawił się jeździec [Staś - M.B.] trzymający przed sobą duży, białawy przedmiot [Nel - M.B.]. [P: 383] ${ }^{9}$

Ponadto w badanej powieści wielokrotnie sygnalizowana jest znaczna różnica koloru skóry między mieszkańcami poszczególnych regionów Afryki, zarówno Arabami, jak i ludnością murzyńską, np.

Jakoż po chwili weszła wysoka, młoda Sudanka [Fatma - M.B.], z twarzą zupełnie nie osłoniętą, o bardzo ciemnej cerze i przepięknych, lubo dzikich i trochę złowrogich oczach. [P: 19]

Księżyc oświecał ich [Idrysa i Gebhra - M.B.] bardzo ciemne twarze, które przy jego blasku wyglądały jakby wykute z brązu. [P: 35]

Ale tymczasem w mdłym świetle ogniska pojawił się ciemnoskóry Gebhr [...]. [P: 55]

Nie zważajcie na jego [Chamisa - M.B.] słowa - odpowiedział Staś - bo on ma nie tylko skórę, ale i mózg ciemny. [P: 58]

[...] Idrys zamyślił się jednak i ciężka troska odbiła się na jego ciemnej twarzy [...]. [P: 96]

9 Biała sylwetka Nel jest efektem nie tyle barwy jej nieosłoniętej, nagiej skóry, ile noszonej przez nią białej odzieży. Strój tego koloru nosi także Staś [P: 338, 371]. 
Staś, który wyobrażał sobie, że mieszkańcy Sudanu różnią się od wszystkich Arabów zamieszkujących Egipt tym tylko, że wierzą w Mahdiego i nie chcą uznać władzy chedywa, spostrzegł, że omylił się zupełnie. Ci [Arabowie w Sudanie M.B.], którzy zatrzymywali teraz co chwila karawanę, mieli po większej części skórę ciemniejsza nawet niż Idrys i Gebhr, a w porównaniu z dwoma Beduinami prawie czarna. Krew murzyńska przeważała w nich nad arabską. [P: 112]

Był to człowiek [Mahdi - M.B.] w średnim wieku, dziwnie otyły, jakby rozpuchnięty, i prawie czarny. [P: 128]

Ach! - pomyślał Staś - więc to nie byli Europejczycy, tylko Arabowie, których Murzyni z powodu ich jaśniejszej cery i białych ubrań poczytali za białych. $[\mathrm{P}: 289]^{10}$

Sporo miejsca w powieści zajmują informacje o zmianach zabarwienia skóry widocznych m.in. na twarzy i rękach Nel w związku z pogarszającym się lub poprawiającym stanem jej zdrowia, np.

Ale zauważywszy [Staś - M.B.], że twarz dziewczynki trochę pobladła, począł wołać na Beduinów [...]. [P: 44]

Może [Nel - M.B.] wychudła trochę i jasna twarzyczka sczerniała jej od wiatru [...]. [P: 91-92 $]^{11}$

Po trzech tygodniach od dnia wyjazdu z Omdurmanu Nel nie zapadła wprawdzie jeszcze na febrę, ale twarz jej schudła i zamiast opalić się, stawała się coraz przezroczystsza, a jej małe rączki wyglądały jakby ulepione z wosku. [P: 150]

Czas jakiś stał jak błędny [Staś - M.B.], po czym spostrzegłszy zbielała twarzyczkę Nel i jej na wpół przytomne, rozszerzone z przerażenia oczy, skoczył ku niej [...]. [P: 163]

[...] zbiedzona dziewczynka [Nel - M.B.] wyglądała ze swoją bladą i przezroczystą twarzyczką istotnie więcej na księżycową niż ziemską istotę. [P: 177]

10 W przywołanym kontekście jest mowa o kupcach arabskich przybyłych przed laty do murzyńskiej wioski plemienia Wa-hima, do którego należał Kali.

11 W cytowanym kontekście czasownik sczernieć oznacza 'opalić się', a nie 'stać się czarnym, czarniejszym niż poprzednio'. 
Nel była już przebrana w suchą odzież, ale wyglądała tak mizernie i blado, że Staś zląkł się o nią [...]. [P: 199]

Twarzyczka jej ożywiła się i nabrała lekkich kolorów [...]. [P: 203]

Cerę miała żółtą i przeźroczysta, usta poczerniałe, oczy podkrążone i twarzyczkę jakby postarzałą. [P: 248]

Więc [Staś - M.B.] patrząc na jej woskową twarzyczkę mówił sobie codziennie: „Na tomże strzegł jej jak oka w głowie, żeby tu ją pochować w dżungli?”. [P: 249]

Staś odchyliwszy płócienną ścianę ujrzał przy świetle kaganka jej blada twarz i białe chude rączki leżące na pledzie, którym była przykryta. [P: 262]

Policzki jej popełniały; cera z żółtej i przeźroczystej stała się na powrót różana [...]. [P: 285]

Staś widział wyraźnie jego [lamparta - M.B.] zielone oczy wpatrzone w biała jak kreda twarz dziewczynki [...]. [P: 324]

Twarzyczka jej, zamiast opalać się na słońcu i wietrze, czyniła się z każdym dniem bledsza [...]. [P: 359]

Więc dziewczynka podniosła swą bladą twarzyczkę ku górze i utkwiwszy oczy w srebrnej tarczy księżyca, poczęła błagać o ratunek [...]. [P: 367]

A w końcu [Staś - M.B.] widział już tylko blada, bardzo kochaną twarzyczkę [Nel - M.B.]. [P: 372]

Twarz drugiego z dwojga bohaterów, czyli Stasia, zmienia swój koloryt pod wpływem słońca lub silnych emocji ${ }^{12}$, np.

Twarz mu zbladta [...]. [P: 134]

12 Dzieje się tak jedynie w momentach nadzwyczajnego zagrożenia życia dzieci, np. w trakcie audiencji u Mahdiego i konieczności sprzeciwienia się jego woli, w czasie niespodziewanego spotkania karawany z lwem, w momencie ataku lamparta na Nel, gdy Nel choruje na febrę, a Staś nie ma już dla niej chininy i wie, że grozi jej śmierć. 
Na wychudłych, opalonych przez pustynny wicher policzkach wykwitły mu jasne rumieńce [...]. [P: 136]

A Staś pobladt śmiertelnie [...]. [P: 159]

I nagle uczuł, że nos i policzki bledna mu znowu, ale było to inne zimno, płynące nie ze strachu, lecz strasznego i nieubłaganego postanowienia, od którego serce w piersiach czyni się na razie żelazne. [P: 162]

Sam wychudł i sczerniał także, albowiem nieszczęście przechodziło jego siły i jego rozum. [P: 249]

Sam wychudł i sczerniał, co było dowodem, że febra się go nie ima, gdyż chorzy na nią nie opalają się na słońcu [...]. [P: 285]

Smagła twarz jego zmieniła się zupełnie tak samo jak wówczas, gdy zastrzelił Gebhra, Chamisa i dwóch Beduinów. Oczy błysnęły mu złowrogo, zacisnęły się wargi i pięści, a policzki pobladty. [P: 310]

Oto ten sam Staś, który przed chwilą byłby zdumiał swą zimną krwią i spokojem najwytrawniejszych strzelców całego świata, pobladt nagle [...]. [P: 326] ${ }^{13}$

Podobnie jak Staś, czyli gwałtownym zblednięciem, reaguje na wiadomość o porwaniu dzieci pan Rawlison:

Podczas tego opowiadania twarz pana Rawlisona stała się biała jak papier. [P: 50]

Natomiast na pustyni, w momencie niemal bliskim śmierci z pragnienia, Stasiowi wydaje się, że widzi czerwone plamy poruszające się przed oczami, np.

Przed oczyma zaczęły mu latać czerwone plamy [...]. Przed oczyma latały mu ciągle czerwone płaty. [P: 369]

U Arabów i Murzynów przeżywane emocje lub choroby również uwidaczniają się na ich twarzach, chociaż w nieco inny sposób niż u Europejczyków, np.

13 Przeżywane emocje mogą się też uwidaczniać w inny sposób, np. „Stasiowi pociemniało w oczach [na wiadomość o zdobyciu Chartumu przez wojska Mahdiego - M.B.]” [P: 105]; „Na widok zwierza [lwa - M.B.] pociemniało mu w oczach” [P: 160]. 
Zrozumiał to tak samo i Idrys, który ochłonąwszy przybiegł do Stasia z twarzą popielatą z przerażenia [...]. [P: 105]

Ciała ich były barwy popielatej, co u Murzynów oznacza bladość. [P: 269]

Słoń trąbił tryumfalnie, a popielaty z przerażenia Nasibu opowiadał Stasiowi, co się stało. [P: 292]

Młody Murzyn [Kali - M.B.] spojrzawszy na zabite zwierzę cofnął się nagle i twarz stała mu się od razu popielata [...]. [P: 326]

Ranny Fumba, ojciec Kalego, przyniesiony na włóczniach wojowników, tuż przed swoją śmiercią ma pobladłe wargi [P: 341], świadczące o beznadziejnym stanie jego zdrowia. Natomiast wówczas, gdy Murzynom (Kalemu i Mei) nie brakuje pożywienia i wody, ich czarna skóra zaczyna świecić jak ciemny atłas [P: 290]. Przeżywana przez Arabów i Murzynów radość, podobnie jak u Europejczyków, daje wrażenie rozjaśnienia ich twarzy, np.

Co się stało - mówił z rozjaśniona twarzą naczelnik. - Oto tymczasem Mahdi zdobył Chartum [...]. [P: 108]

Uwagę powieściowego narratora zwraca także nietypowa barwa ciał osób zabitych w czasie walk w Chartumie oraz kolor objedzonych przez mrówki szkieletów Murzynów w opuszczonej afrykańskiej wiosce, którą wskazał Stasiowi Linde, np.

Nie zarażały one [ciała zabitych w Chartumie - M.B.] jednak powietrza, gdyż słońce sudańskie wysuszyło je na mumie, wszystkie miały barwę szarego pergaminu, tak jednostajną, że ciał Europejczyków, Egipcjan i Murzynów nie można było odróżnić. [P: 119]

Przed chatami leżały tu i ówdzie kości i całe kościotrupy ludzkie białe jak kreda, albowiem oczyszczone przez mrówki [...]. [P: 278]

Stosunkowo niewiele uwagi poświęcił pisarz kolorystyce różnych innych części ciała charakteryzowanych bohaterów. W tym wypadku najwięcej informacji dotyczy postaci Nel. Wiadomo, jaki kolor mają jej oczy i włosy, jakie zmiany wywołują w jej wyglądzie choroba i przeżywane emocje, np. 
A mała, podobna do ślicznego obrazka Nel podniosła swe zielonawe oczy na Stasia i zapytała ze zdziwieniem [...]. [P: 7]

Na to źrenice Nel zapłonęły z radości jak dwa zielonawe ogniki. [P: 223]

Zaś ,dobre Mzimu” wytrzeszczyło na niego [na Kalego - M.B.] swoje śliczne, koloru morskiej wody oczy, nie rozumiejąc wcale, co się stało [...]. [P: 227]

Nawet źrenice jej [Nel - M.B.] wydawały się bledsze niż zwykle [w wyniku ataku febry - M.B.]. [P: 248]

Dziewczynka skinęła swoją płowa główką na znak, że bardzo jej o to chodzi. [P: 155]

I chcąc wzbudzić jej zaufanie, a zarazem dodać otuchy, [Staś - M.B.] począł ją głaskać po płowej główce. [P: 171]

I pobladłe usta poczęły się jej [Nel - M.B.] trząść. [P: 171]

Cerę miała żółtą i przeźroczystą, usta poczerniałe, oczy podkrążone i twarzyczkę jakby postarzałą. [P: 248]

O Stasiu wiemy jedynie tyle, że jego oczy były szare:

A Staś zmarszczył brwi i począł patrzeć swymi stalowymi oczyma w oczy Kalego [...]. [P: 344]

Tylko raz narrator informuje czytelników o tym, że w mroku białka oczu Arabów (Idrysa i Gebhra) połyskiwały zielonawo spod turbanów [P: 35].

Ponadto uwagę powieściowych bohaterów, a zwłaszcza Stasia, zwraca nietypowa barwa włosów przebywających w Chartumie wojowników Mahdiego:

[...] prości wojownicy nosili głowy odkryte, lecz nie golone tak jak Arabowie w Egipcie, ale przeciwnie, porośnięte ogromnymi, kręconymi kudłami, spalonymi często na kolor czerwony od wapna, którym namazywali czupryny dla ochrony przed robactwem. [P: 112 $]^{14}$

14 Byli to, jak stwierdza narrator, Arabo-Murzyni, czyli mieszańcy obu ras, w których krew murzyńska przeważała nad arabską [P: 112]. 
Biały kolor mają włosy na czaszce, zatkniętej na bambusowym kiju, zamordowanego przez mahdystów generała Gordona, dowódcy wojsk w Chartumie [P: 126], i włosy panów Tarkowskiego oraz Rawlisona, gdy powracają do nich porwane dzieci:

Twarz tej głowy [Gordona - M.B.] była wyschnięta i prawie czarna, natomiast włosy na czaszce i brodzie biate jak mleko. [P: 126]

Dzieci dziwiły się tylko, że głowy tatusiów pobielaty podczas rozłąki zupełnie. [P: 390]

Uwagę narratora, a w konsekwencji również czytelników, zwraca także wyraźnie odbijająca się biel zębów na tle ciemnej karnacji skóry Arabów i Murzynów, np.

Staś natychmiast zapytał Chamisa, co znaczy to wszystko, co się stało, ale ów, śmiejąc się ukazał mu tylko swe białe zęby [...]. [P: 55]

Niektórzy z dzikich [w Chartumie - M.B.] wybuchali na ich widok śmiechem [...], niektórzy ryczeli jak dzikie zwierzęta, wyszczerzając białe zęby i przewracając oczyma [...]. [P: 119]

Na to - znany ze srogości i okrucieństwa kalif Abdullahi zabłysnął swymi białymi zębami jak dziki zwierz [...]. [P: 136]

I na tę myśl opanowała go [Kalego - M.B.] taka radość, że jął skakać, uderzać dłońmi po kolanach i śmiać się jak szalony, przewracając przy tym oczy i połyskując biatymi zębami. [P: 209] ${ }^{15}$

Informacje o kolorze ludzkich, a nie zwierzęcych języków pojawiają się w powieści w kontekście obrzędu zawierania braterstwa między przywódcami plemion murzyńskich. Jedno z wypowiadanych w trakcie rytuału zaklęć wspomina o tym, że wiarołomstwo będzie ukarane sczernieniem języka wiarołomcy. W opisywanym obrzędzie prowadzący ceremoniał stary Murzyn wypowiada magiczne słowa: „A język jego niechaj stanie się czarny!”, a otaczający go współplemieńcy powtarzają za nim słowo: „Czarny” [P: 315].

15 Informacje dotyczące białej barwy zębów pojawiają się także, chociaż rzadko, przy opisach zwierząt, np. Saby przygotowującego się do obrony dzieci przed uderzeniami Beduina [P: 84] i goryla porywającego Nasibu [P: 292]. 
Przy okazji katechizacji, a potem chrztu Kalego i Mei pojawia się także wzmianka o zabawnym nieporozumieniu, związanym z tym, że dwoje Murzynów spodziewało się po przyjęciu sakramentu chrztu zmiany koloru skóry $\mathrm{z}$ czarnego na biały. Zawiedzionym brakiem jakiejkolwiek zmiany w tym zakresie dzieci tłumaczą, że na biały zmienił się jedynie kolor ich mózgów (dusz), a nie skóry, np.

Wa-hima mają czarne mózgi [są poganami - M.B.], ale twój mózg powinien być biały [jako chrześcijanina - M.B.]. [P: 344]

- tak tłumaczy Staś Kalemu różnicę między poganami i chrześcijanami. W efekcie tych wywodów młody Murzyn stwierdza:

Kali mieć teraz bialy mózg! [P: 345]

Podobnie zareagowała na obrzęd chrztu Mea:

Mea czuła się wszelako nieco zawiedziona, albowiem w naiwności ducha rozumiała, że po chrzcie wybieleje natychmiast na niej skóra, i wielkie było jej zdziwienie, gdy spostrzegła, że pozostała czarna jak i przedtem. Nel pocieszyła ją jednak zupełnie zapewnieniem, że teraz duszę ma biała. [P: 286]

Czarny lub ciemny mózg może być także w powieści metaforycznym określeniem głupoty, np.

Nie zważajcie na jego [Chamisa - M.B.] słowa - odpowiedział Staś - bo on ma nie tylko skórę, ale i mózg ciemny. [P: 58]

Mea mieć czarną skórę i czarny mózg [...]. [P: 218]

Kolejną wyraźnie wyodrębniającą się w badanej powieści grupę realiów, którym przyporządkowano jakieś konkretne lub określone tylko ogólnie barwy, tworzą ubiory, tkaniny i akcesoria stroju. Wszyscy występujący w utworze Europejczycy oraz znaczna część Arabów używają odzieży w kolorze białym, np.

[...] tymczasem dwaj ludzie [Idrys i Gebhr - M.B.], przybrani w białe burnusy, stanęli przed namiotami. [P: 35] $]^{16}$

$16 \mathrm{~W}$ nocy na pustyni burnusy Arabów pod wpływem gry światła zabarwiały się różowo [P: 54]. 
Staś ujrzał wyraźnie leżących obok siebie Arabów, a pod drugą ścianą jaskini biała sukienkę Nel śpiącej przy Dinah. [P: 78]

Niektórzy [Arabo-Murzyni z wojska Mahdiego - M.B.] byli prawie nadzy, inni nosili dżiuby, czyli opończe z białej tkaniny bawełnianej naszywanej W różnobarwne łatki. [P: 112]

Przekupnie [na targu w Omdurmanie - M.B.], głównie zaś kobiety sudańskie i Murzynki, sprzedawali tu dżiuby, to jest białe płócienne chałaty ponaszywane w różnokolorowe płatki [...]. [P: 126]

Przybrany był [Mahdi - M.B.] w biała dżiubę i biała krymkę na głowie, a nogi miał bose, gdyż wstępując na podwyższenie zrzucił czerwone ciżmy [...]. [P: 128]

Starzy ludzie mówić u nas, że widzieli białych ludzi [...]. Było trzech [kupców arabskich handlujących kością słoniową - M.B.] w długich białych sukniach. [P: 176]

Pierwszym przedmiotem, który uderzył jego [Stasia - M.B.] oczy, był wielki namiot; przed namiotem stało polowe płócienne łóżko, a na nim leżał człowiek [Linde - M.B.] przybrany w biały ubiór europejski. [P: 257]

Ach! - pomyślał Staś - więc to nie byli Europejczycy, tylko Arabowie [kupcy arabscy handlujący kością słoniową - M.B.], których Murzyni z powodu ich jaśniejszej cery i białych ubrań poczytali za białych. [...] - Czy Wa-hima nie zabili żadnego z tych biało ubranych ludzi? [P: 289]

[...] przy błyskawicach wystrzałów ujrzeli olbrzymie zwierzę, a na nim biało przybranego człowieka [Stasia - M.B.]. [P: 338]

Promienie księżyca rozświecały prócz namiotów białe ubrania Stasia i Nel [...]. [P: 371]

Doktor [Clary - M.B.] zdjął z głowy biały hełm i obtarł spocone czoło. [P: 381].

Nel, poza białą sukienką, ma także na początku podróży pięciopalczaste jasne rękawiczki, które za radą Stasia upuszcza na drogę, aby ułatwić pościg [P: 53, 55]. 
Jak wynika z przywołanych wyżej cytatów, służący w armii Mahdiego Arabo-Murzyni ozdabiali swoje białe stroje (dżiuby) różnokolorowymi/różnobarwnymi łatkami, zaś sam Mahdi poza białą dżiubą nosił na bosych stopach czerwone ciżmy. Przywódcy wojskowi

okrywali głowy białymi krymkami z takiejże tkaniny jak i opończe [P: 112],

a zwykli prości wojownicy mieli - jak zauważa narrator - odkryte głowy.

Widziani przez dzieci z okien pociągu w Egipcie Arabowie, chociaż inaczej ubrani niż mahdyści, również zwracali uwagę obserwatorów swoim strojem, przypominającym ubiory noszone przez biblijnych Izraelitów:

Przed każdym wielbłądem szedł Arab w czarnym płaszczu i białym zawoju na głowie. [P: 26]

Natomiast naczelnik stacji kolejowej w El-Gharak, Egipcjanin z pochodzenia, w kolejowym uniformie, nosił na głowie charakterystyczny czerwony fez, a na nosie ciemne okulary [P: 43, 49] ${ }^{17}$.

Kilkakrotnie w powieści pojawiają się również informacje o kolorze tkanin i paciorków, którymi Staś obdarowywał spotkanych w wioskach Murzynów, np.

Trwało to dopóty, dopóki Staś nie powstrzymał tego napływu zapasów, a ponieważ zapłacił za nie hojnie paciorkami i kolorowym perkalem [...], przeto radość niezmierna zapanowała w całej wsi [...]. [P: 314]

Zachwycone niewiasty biły pokłony nawet Mei, która, przybrana w różowy perkal i w kilka sznurów niebieskich paciorków, wydała im się także, jako służka Mzimu, istotą daleko od zwykłych Murzynek wyższą. [P: 336]

Pozostałe realia, których kolorystyka została scharakteryzowana na kartach powieści Sienkiewicza, nie tworzą już tak licznych i zwartych grup, jak omówione wyżej. Znalazły się wśród nich przede wszystkim określenia domów mieszkalnych, amerykańskich studziennych wiatraków i namiotów, które wyróżniają się na tle otoczenia swym białym kolorem, np.

17 W powieści pojawiają się również opisy ubiorów noszonych przez inne osoby, np. przez Murzynów [P: 312], ale nie zawierają już one żadnych określeń kolorystycznych. 
Białe mury budynków miejskich naprzeciw namiotów [w nocy - M.B.] świeciły zielono [...]. [P: 32]

Kępy smukłych palm i drzew pieprzowych, plantacje mandarynek, białe domy, mały meczet ze strzelistym minaretem, a niżej mury otaczające ogrody, wszystko to pojawiło się z taką wyrazistością i w odległości tak niewielkiej, iż można było mniemać, że po upływie pół godziny karawana znajdzie się wśród drzew oazy. [P: 92 $]^{18}$

Palankin, o którym zapomniano, na grzbiecie Kinga, i namioty błyszczały tak, jak błyszczą w jasne noce domy wybielone wapnem. [P: 371]

Jakoż istotnie w oddali błyszczały wysoko wzniesione wiatraki studni amerykańskich podobne do wielkich białych gwiazd. Na zielonym tle drzew widać je było tak dokładnie, że bystry wzrok Stasia mógł odróżnić pomalowane na czerwono brzegi skrzydeł. [P: 93 $]^{19}$

Po chwili uwage jego [Stasia - M.B.] zwrócił jakiś białawy przedmiot [dach namiotu - M.B.] zaplątany w pnącze [...]. [P: 198]

Kilkakrotnie w powieści powracają także wzmianki o kolorze palankinu (namiotu), usytuowanego na grzbiecie słonia, którym podróżuje Nel, np.

[...] nad rozkołysaną zieloną powierzchnią [stepu porośniętego wysoką trawą M.B.] widać było tylko biały palankin, który posuwał się naprzód jakby statek na jeziorze. [...] Stada [zwierząt - M.B.] na widok karawany przestawały się paść, podnosiły głowy i strzygąc uszami patrzyły na biały palankin z nadzwyczajnym zdumieniem [...]. [P: 295]

Wszystkie oczy wlepione były w Kinga, w biały palankin i w siedzącego na karku słonia białego człowieka. [P: 304]

Oto dobre Mzimu siedzi tam, w tej białej chacie na grzbiecie wielkiego słonia [...]. [P: 305]

18 W rzeczywistości jest to jednak tylko typowe dla obszarów pustynnych zjawisko optyczne nazywane fatamorganą.

19 O wynajętych przez panów Tarkowskiego i Rawlisona w Medinet-el-Fajum namiotach wiadomo jedynie, że były one podbite kolorową flanelą: „Okazało się, że są wspaniałe [namioty - M.B.], podwójne, podbite jedne niebieska, drugie czerwona flanelą [...]” [P: 30]. 
Gdy jednakże po upływie kilku godzin [murzyńskie kobiety z plemienia Wa-hima - M.B.] ujrzały olbrzymiego słonia zbliżającego się do wałów, a na nim biały palankin, wpadły w szał radości [...]. [P: 336]

Staś chronił Nel, jak mógł, od słońca i nie pozwalał jej wychylić się ani na chwilę spod palankinu, którego daszek pokrył sztuką białego perkalu, aby go uczynić podwójnym. [P: 368]

Puszczane przez Stasia latawce, wykonane z rybich pęcherzy, także mają biały kolor, np.

Król [w wiosce murzyńskiej - M.B.] opowiadał o tym fetyszu [puszczonym przez Stasia latawcu - M.B.], że spadł niedawno z księżyca, że był biały i że miał ogon. [P: 320]

Kilku z nich [Murzynów - M.B.] wróciło do obozu przed zachodem słońca niosąc jakieś kwadratowe białe przedmioty, w których Staś rozpoznał swoje własne latawce. [P: 360]

Zupełnie sporadycznie w badanej powieści pojawiają się wzmianki o kolorystyce innych przedmiotów, np. angielskich parowców, świateł lokomotywy czy chorągwi w wojskach Mahdiego, np.

Czy nie mieszka tam biały naczelnik, który ma czarne dymiące łodzie [parowce-M.B.] i wojsko? [P: 176]

Po chwili w ciemności ukazały się ogniste oczy lokomotywy [...]. Szereg oświeconych wagonów przesunął się wzdłuż peronu, zadrgał i stanął. [P: 48]

Po bokach pozatykane były chorągwie emirów, które łopotały na wietrze, mieniac się i grając wszelkimi barwami jak wielkie kwiaty. [P: 128]

\section{$* * *$}

Podsumowując badania dotyczące kolorystyki świata przedstawionego w powieści W pustyni i w puszczy Sienkiewicza, trzeba stwierdzić, że nie jest to sprawa potraktowana przez pisarza jedynie marginalnie, co może nieco zaskakiwać, jeśli weźmie się pod uwagę charakter utworu (powieść przygodowa dla młodzieży nastawiona raczej na wartką, przyciągającą uwagę fabułę, a nie na roz- 
budowaną odautorską narrację). Przy prezentacji barw afrykańskich realiów najwięcej miejsca poświęcił pisarz florze i faunie tego kontynentu, zwłaszcza zaś ubarwieniu egzotycznych dla Polaków zwierząt. Głównie są to opisy kolorystyki ptasiego upierzenia, rzadziej informacje o barwach tropikalnych roślin. Być może zadecydowały o tym myśliwskie upodobania Sienkiewicza. Pojawiające się w powieści opisy przyrody rzadko dotyczą detali (np. widzianych z bliska egzotycznych kwiatów czy ptaków), najczęściej opisywane obiekty postrzegane są przez narratora jako barwne plamy malujące się na kontrastowym tle (np. żółte, różowe lub białe kwiaty na tle intensywnej zieleni).

Z przywoływanych w powieści opisów widać także, że stosunkowo często zainteresowanie pisarza budziły zmiany kolorów nieba i całego otaczającego świata, uzależnione od pory dnia, warunków atmosferycznych, oświetlenia (np. zmieniający swą barwę na liliową kolor pustynnego piasku i pól o zachodzie słońca, tęczowa gra świateł na jeziorze). Natomiast zdecydowanie mniej uwagi poświęcił pisarz kolorystyce związanej z ludźmi, np. z barwą ich ubiorów, ozdób ${ }^{20}$. W opisach ludzi dominującą pozycję zajmują przede wszystkim różnice rasowe, uwidocznione m.in. odmienną barwą skóry Europejczyków i Arabów oraz Murzynów. Widać także odmienność upodobań przedstawicieli poszczególnych ras w zakresie kolorystyki strojów: Europejczycy ze względów klimatycznych preferują białą odzież, Arabowie białą lub czarną, a Murzyni kolorową.

Wzmianki o kolorystyce prezentowanych osób czy przedmiotów występują w powieści Sienkiewicza ponad 400 razy, a więc stosunkowo często, jeśli weźmie się pod uwagę niewielką objętość utworu ${ }^{21}$. W opisach tych zdecydowanie dominują dwa kolory: biały i czarny, co wiąże się z mocno eksponowanymi na kartach powieści różnicami rasowymi między Europejczykami i rdzennie afrykańską ludnością murzyńską. Biały kolor skóry głównych bohaterów (i biały kolor noszonych przez nich ubiorów) symbolizuje zachodnioeuropejską cywilizację, czarny (dodatkowo wyeksponowany skąpym strojem lub nagością Murzynów) jest synonimem pierwotnych, niecywilizowanych sił bliskich naturze - prymitywnych i nieoświeconych, ale ze swej natury dobrych. Występujący

20 W Trylogii Sienkiewicza proporcje są nieco inne, ponieważ na pierwsze miejsce wysuwa się charakterystyka kolorystyczna powieściowych bohaterów, a nie przyrody. Opisy barw przyrody i zjawisk wizualnych związanych ze światłem i ciemnością plasują się dopiero na drugim miejscu pod względem frekwencji. Według Krystyny Siekierskiej [1988a: 324-331; 1988b: 177-193; 1988c: 114] są to zwykle informacje bardzo konwencjonalne i mało szczegółowe, zwłaszcza jeśli chodzi o kolorystykę świata roślin i zwierząt (np. koni).

21 Analizowana w artykule powieść, w wykorzystanym wydaniu, obejmuje - wraz z dołączonymi do tekstu ilustracjami - 393 strony, natomiast badana przez Siekierską [zob. 1988c: 114] Trylogia liczy 3465 stron. 
w powieści Arabowie są grupą pośrednią między białymi Europejczykami i czarnymi Afrykanami. Prezentują oni różne odcienie skóry ze względu na wymieszanie krwi arabskiej z murzyńską, zwłaszcza w południowej części Sudanu.

Poza bielą i czernią, w badanej powieści istotną rolę odgrywa także pole czerwieni, a dalej kolejno - według częstości występowania - pojawiają się pola takich barw, jak: zieleń, żółć, błękit, róż, szarość, srebro, złoto, brąz, fiolet oraz pole barw niejednolitych ${ }^{22}$. W szczegółach przedstawia się to następująco: pole bieli jest wzmiankowane w badanej powieści 137 razy, czerni - 74 razy, czerwieni - 47 razy, zieleni - 25 razy, żółci - 23 razy, błękitu i różu - każdy z kolorów po 21 razy, szarości - 18 razy, srebra - 11 razy, brązu i złota - każdy z kolorów po 10 razy, fioletu - 5 razy i pole wielobarwne 16 razy $^{23}$. Odrębną grupę w stosunku do wymienionych wyżej pól kolorystycznych tworzy pole sygnalizujące różne natężenie światła (tzw. pole światłocienia), które u Sienkiewicza odgrywa dość istotną rolę (zarówno w badanej powieści, jak i w Trylogii) [zob. Siekierska 1988c: 114].

W podanym wyżej zestawieniu na uwagę zasługuje przede wszystkim dość wysokie usytuowanie wśród nazw kolorów pola zieleni, które w Trylogii uplasowało się znacznie dalej, tzn. dopiero po złocie, żółci, błękicie, szarości, różu i srebrze [zob. Siekierska 1988c: 108²4, 113]. W obu utworach na czoło listy wysuwają się natomiast konsekwentnie trzy pola kolorystyczne, tj.: bieli, czerni i czerwieni ${ }^{25}$. Poza wysoką frekwencją w tekście pola te cechuje także

22 Przy wydzielaniu pól kolorystycznych korzystam z propozycji przyjętej w pracy Kwiryny Handke [2002] poświęconej leksyce barw w utworach Stefana Żeromskiego. Nieco odmienny podział proponują w swoich artykułach inni autorzy, np. Mirosława Ampel-Rudolf [1994], Joanna Rychter [2014], Krystyna Siekierska [1988abc], Ryszard Tokarski [1995], Alfred Zaręba [1954].

23 W skład każdego z wymienionych wyżej pól kolorystycznych mogą wchodzić różne części mowy (np. przymiotniki, przysłówki, czasowniki, rzeczowniki), a także struktury bardziej rozbudowane (np. porównania, metafory, metonimie). W obliczeniach pominięto nazwy własne zawierające odniesienia do koloru (np. Biały Nil, Ciemna Woda, Czarna Woda, Morze Czerwone, Niebieski Nil) oraz formacje słowotwórcze motywowane nazwami kolorów (np. białko 'część ptasiego jaja otaczająca żółtko; część gałki ocznej otaczająca tęczówkę', czerwonak 'nazwa ptaka', krasnodzióbek 'nazwa ptaka', rumieniec 'różowe zabarwienie policzków', siniec 'sinoczerwone zabarwienie skóry powstające wskutek podskórnego wylewu krwi', żótć ‘żółtobrunatna wydzielina wątroby zwierząt kręgowych i człowieka').

24 Tabela 1. Przymiotnikowe nazwy barw w Trylogii.

25 Rozkład i zasobność poszczególnych pól kolorystycznych oraz frekwencja leksemów określających barwy wygląda bardzo podobnie w Trylogii Sienkiewicza i w badanej przeze mnie powieści, mimo znacznej różnicy w objętości obu tekstów. Ogromną przewagę frekwencyjną mają w Trylogii przymiotniki biały, czarny i czerwony, co sugeruje dominację tych trzech 
stosunkowo duża zasobność i różnorodność określeń, czyli bogata synonimika, i uwzględnianie bogactwa odcieni trzech wymienionych wyżej barw. Przy okazji trzeba jednak wspomnieć, że dominacja wymienionych kolorów nad pozostałymi polami barw jest charakterystyczna nie tylko dla Sienkiewicza, ale także dla innych polskich i obcych pisarzy (np. dla Bolesława Prusa czy Michaiła Szołochowa) [zob. Siekierska 1988c: 113].

Wykorzystana w powieści leksyka należąca do pola barw, jakkolwiek dość bogata i semantycznie oraz formalnie zróżnicowana, nie jest jednak zbyt oryginalna. Zdecydowanie dominują tu typowe określenia przymiotnikowe używane w znaczeniach podstawowych, a nie metaforycznych, takie jak: biały, blady, błękitny, ciemny, czarny, czerwony, jasny, niebieski, płowy, purpurowy, różowy, srebrny, srebrzysty, szary, wiśniowy, zielony, złoty czy żótty, oraz bliskoznaczne przysłówki, np. biało, błękitno, ciemno, czarno, czerwono, różowo, srebrno, wiśniowo, zielonawo, zielono, złoto. $\mathrm{W}$ analizowanym materiale przykładowym spotykamy także określenia barw w formie rzeczowników (np. ametyst, bladość, błękit, ciemność, opal, pobielenie, purpura, rubin, zieloność, złoto) i czasowników (np. blednać, czernić się, czernieć, czerwienić się, pobielić, poblednać, pociemnieć, poczernieć, posrebrzeć, poszarzeć, rozsrebrzać, różowieć, sczernieć, sinieć, ściemnić się, wybieleć, wybielić, zabielić się, zaczerwienić, zbieleć, zblednać, złocić się).

W opisach kolorystycznych prezentowanych w powieści realiów Sienkiewicz zazwyczaj posługuje się leksemami najczęściej stosowanymi, nie precyzując odcieni poszczególnych barw, np. biaty, czarny, czerwony, zielony, żólty, niebieski, różowy, szary, srebrny, złoty. Znacznie rzadziej pisarz korzysta z określeń sygnalizujących różne odcienie kolorystyczne, typu: biały - biatawy, śnieżny, *brązowy - brunatny, kasztanowy, opalony, rudy, smagty ${ }^{26}$, czerwony - koralowy, krwawy, ognisty, purpurowy, wiśniowy, niebieski błękitnawy, błękitny, granatowy, jasnoniebieski, sinawy, siny, siwobłękitny,

podstawowych barw. Największą gamą odcieni wyróżnia się u Sienkiewicza czerwień, choć liczebnie zajmuje dopiero trzecie miejsce po bieli i czerni. Czwartą bardzo rozbudowaną grupą barw w palecie autora Trylogii są różne odcienie koloru niebieskiego. Dość liczne są także odcienie brązu i szarości, choć mają one bardzo niską frekwencję. Dalekie miejsce zajmuje, jak już wspominałam, zieleń. Zdaniem Siekierskiej wiąże się to z nielicznymi i bardzo oszczędnymi opisami przyrody w Trylogii. Na uwagę zasługuje też sformułowana przez cytowaną wyżej autorkę ogólna uwaga, że w całej Trylogii nazw kolorów jest mało i są one rzadko używane, co może nieco zaskakiwać, gdy weźmie się pod uwagę objętość tekstu i jego walory językowe oraz artystyczne [zob. Siekierska 1988c: 112-113].

$26 \mathrm{~W}$ badanej powieści brak przymiotnika brązowy, pojawiają się jedynie inne określenia tego koloru o zbliżonej frekwencji, w związku z czym trudno uznać jedno z nich za podstawową nazwę tego koloru w języku pisarza. 
różowy - różany, srebrny - srebrzysty, szary - płowoszary, popielaty, stalowy, szyfrowy, zielonoszary, zielony - ciemnozielony, jasnozielony, szarozielony, zielonawy, żółty - cynamonowy, płowożółty, płowy, woskowy.

Najliczniej zostało udokumentowane w powieści pole czerwieni (np. czerwonoskóry, czerwony, koralowy, krwawy, ognisty, purpurowy, wiśniowy, zaczerwieniony; czerwono, pasowo, wiśniowo; purpura, rubin; czerwienić się, zaczerwienić się) ${ }^{27}$, dalej zaś kolejno: pole bieli (np. białawy, biały, pobladty, śnieżny, wybielony, zbielaty; biało; pobielenie; blednąć, bielić się, pobieleć, poblednać, wybieleć, zabielić się, zblednać), błękitu (np. błękitnawy, błękitny, granatowy, jasnoniebieski, niebieski, sinawy, siny, siwobłękitny; błękitno; błękit; sinieć), zieleni (np. ciemnozielony, jasnozielony, koloru morskiej wody ${ }^{28}$, szarozielony, zielonawy, zielony; zielonawo, zielono; zieloność $)^{29}$, a także czerni (np. barwy węgla, czarny, poczerniaty, sczerniały; czarno; czernieć, czernić się, sczernieć), szarości (np. płowoszary, popielaty, stalowy, szary, szyfrowy, zielonoszary; poszarzeć), brązu (np. brunatny, kasztanowy, opalony, rudy, smagły; opalać się, opalić się) ${ }^{30}$, zółci (np. cynamonowy, płowożółty, płowy, woskowy, żólty) ${ }^{31}$, srebra (np. srebrny, srebrzysty; srebrno; posrebrzeć, rozsrebrzyć), różu (np. różany, różowy; różowo; różowieć) ${ }^{32}$, zlota (np. złoty; złoto; złocić się) i fioletu (np. lila, liliowy; ametyst).

27 Chodzi tu o liczbę leksemów wchodzących w skład danego pola kolorystycznego, czyli o zasobność pól, ich nasycenie leksyką, a nie o frekwencję poszczególnych wyrazów w polu czy rangę wydzielonych pól kolorystycznych w całej badanej powieści.

28 Morskiej wodzie można przypisywać różne barwy. W powieści Sienkiewicza podane określenie odnosi się jednak tylko do koloru oczu Nel, które w innych miejscach utworu zostały przypisane do pola zieleni.

29 Przy części przykładów pojawia się wątpliwość, do którego pola należałoby je zaliczyć, ponieważ rodzaj nazywanych realiów nie wskazuje tego w sposób całkowicie jednoznaczny (np. zielonoszare ptaszyny, płowoszary zwierz). W tym wypadku przyjęłam zasadę nadrzędności semantycznej drugiego członu w złożeniach przymiotnikowych, jako najbardziej regularną (por. bladoniebieski, ciemnozielony, jasnoniebieski).

30 W polu brązu można by też umieścić niektóre użycia czasownika sczernieć 'opalić się', np. „Sam [Staś - M.B.] wychudł i sczerniat, co było dowodem, że febra się go nie ima, gdyż chorzy na nią nie opalają się na słońcu" [P: 285]. Do tego pola lub do pola czerwieni należy również porównanie jak miedziana blacha, które pojawia się w opisie burzy piaskowej na pustyni: „Grubszy piasek opadł zupełnie; pozostał w powietrzu tylko subtelny, czerwony pył, coś w rodzaju śreżogi, przez którą słońce przeświecało jak miedziana blacha” [P: 73].

31 W tym polu być może należałoby także umieścić określenie jałowa barwa piasków pustyni, które pojawia się w następującym kontekście: „Zieloność pastwisk i akacyj mile nęciła oczy po jednostajnej, jałowej barwie piasków pustyni” [P: 111].

$32 \mathrm{~W}$ tym polu można by też umieścić zwrot nabrać lekkich kolorów pojawiający się w następującym kontekście: „Twarzyczka jej [Nel-M.B.] ożywiła się i nabrała lekkich kolorów” [P: 203]. 
W polu barw niejednolitych znalazły się m.in. takie określenia, jak: pręgowany, pstry, siedmiobarwny, różnobarwny, różnokolorowy, drgać odblaskami pawich piór, mienić się jak opale, mienić się jak tęcza, mienić się i grać wszelkimi barwami jak wielkie kwiaty, być może także przybrać barwę muszli perłowej ${ }^{33}$. Do ogólnych określeń kolorów można zaliczyć przymiotnik kolorowy i wyrażenie jaskrawo upierzony, które mogą sygnalizować zarówno jedno-, jak i wielobarwność opisywanych realiów ${ }^{34}$.

Dość dużą zasobnością wyróżnia się także w powieści pole sygnalizujące różne natężenie światła, od pełnej jasności do całkowitego mroku, np. blady, blado, blask, blednać, jasny, rozjaśnić, światło, ciemny, ciemno, ciemność (np. ciemność tak gęsta, że prawie namacalna), ćma, mrok, pociemnieć, ściemnić się.

Najwyższą frekwencję mają dwa przymiotniki określające kolory, tj. biały (106 użyć w tekście) i czarny (58 użyć), dalej zaś kolejno - według częstości użycia - przymiotniki: czerwony (24), różowy (16), zielony (13), żółty (10), płowy (9), szary (9), srebrny (7), niebieski (6), złoty (6), białawy (5), błękitny (5), purpurowy (5), popielaty (4). Pozostałe leksemy pojawiają się w powieści rzadziej, ich rola nie jest zatem znaczna.

Na uwagę zasługują jeszcze określenia kolorów w formach mniej typowych, np. porównań, metonimii, przenośni. Wśród wyrażeń porównawczych znalazły się określenia często w polszczyźnie używane, takie jak: biały jak kreda/mleko/papier/śnieg, czarny jak aksamit/kir/noc, czarno jak w piwnicy, czerwony jak krew, szary jak mysz, oraz bardziej oryginalne i rozbudowane, chociaż nie odsyłające wprost do afrykańskich realiów, np.

[...] piaski zaczęły przybierać barwę liliowa, taka, jaką maja wrzosy w polskich lasach. [P: 10]

[...] krople spływające z liści, podobne przy blasku ognia do wielkich, różowych peret. [P: 191]

[...] [liany - M.B.] zmieniały je [drzewa - M.B.] w piramidy zasypane białym kwieciem jak śniegiem. [P: 203]

33 Znaczenie tego zwrotu nie jest dziś oczywiste. W grę może tu wchodzić kolor biały, szary lub powierzchnia opalizująca różnymi barwami.

34 Pierwszy z przywoływanych tu przymiotników jest określeniem odnoszącym się do koloru tkaniny, dokładniej perkalu dawanego w prezencie Murzynom [P: 314], a drugi odnosi się do ptaków, dokładnie do tukanów [P: 203]. 
[...] źrenice Nel zapłonęty z radości jak dwa zielonawe ogniki. [P: 223]

[...] bliskie ziemi obłoki barwiły się wiśniowo, górne, lepiej oświecone, rozlewały się na kształt jezior z purpury i złota, a drobne, wełniste chmurki mienity sie jak rubiny, ametysty i opale. [P: 229]

[...] [Nel - M.B.] ujrzała teraz nad sobą trąbę na kształt ogromnego czarnego węża. [P: 230]

[...] gniazda os podobne do wielkich róż, ale koloru szarej bibuty. [P: 247]

[...] wąski, podobny do białej taśmy wodospad. [P: 281]

[...] [ryby wyskakiwały z wody - M.B.] migocac jak srebrne gwiazdy w powietrzu. [P: 281]

[...] skóra na Kalim i Mei poczęła się świecić jak ciemny atłas. [P: 290]

[...] jasne bóstewko [Nel - M.B.] podobne do biatego ptaka i zarazem do białego kwiatu. [P: 308]

[...] prześliczne „bengalis” [ptaki - M.B.] przelatywały mieniąc się jak tęcza. [P: 321]

[...] [dolina zarośnięta krzakami kusso - M.B.] wyglądająca jakjedno różowe jezioro. [P: 330]

[...] można było odróżnić pięć jakby okrągłych czerwonych kwiatów [wystające nad powierzchnię wody czubki trąb słoni wodnych - M.B.]. [P: 355] ${ }^{35}$

Wśród mniej typowych określeń kolorów przykładowo można wymienić jeszcze takie, jak:

[...] lśnić złotem [jezioro o zachodzie słońca - M.B.]. [P: 10]

[...] zabarwić się złotem [chmury o wschodzie słońca - M.B.]. [P: 65]

35 Porównania kolorystyczne pojawiają się także w Trylogii Sienkiewicza, chociaż przywoływane w nich odniesienia na ogół są inne niż w badanej przeze mnie powieści. [zob. Siekierska 1988c: 115-117 (Tabela 4. Porównania barwne w Trylogii)]. 
[...] złote światło [słońca - M.B.]. [P: 228]

[...] drgać odblaskami pawich piór [jezioro o zachodzie słońca-M.B.]. [P: 10]

[...] mienić się kukurydza, prosem, alfalfa [pola uprawne w Egipcie - M.B.]. [P: 26]

[...] mieć barwę czystego ametystu [wzgórza o zachodzie słońca - M.B.]. [P: 44]

[...] przybrać barwę muszli perłowej [niebo o wschodzie słońca-M.B.]. [P: 65]

[...] szyfrowa barwa [skóry słonia - M.B.]. [P: 212] $]^{36}$

[...] koloru morskiej wody [oczy Nel - M.B.]. [P: 227]

[...] płonąć różowym blaskiem [odwieczne śniegi na Kilimandżaro - M.B.]. [P: 387]

Wcześniejsi badacze języka Sienkiewicza, oceniając wrażliwość pisarza na świat kolorów i związaną z nią kolorystykę świata przedstawionego (m.in. w Trylogii i w utworach powstałych w czasie podróży do Ameryki i później), sygnalizowali zgodnie, że nie wykazywał on szczególnych upodobań do charakterystyki uwzględniającej barwy opisywanych realiów [zob. Siekierska 1988abc; Widerman 1969]. Przy przedstawianiu świata interesowali go też zwykle bardziej ludzie niż przyroda czy wytwory rąk ludzkich. Uznano zatem, że pisarz z upodobania był raczej rysownikiem czy rzeźbiarzem, a nie wrażliwym na barwy malarzem kolorystą, chociaż tworzył swe dzieła w okresie popularnego w Europie i w Ameryce impresjonizmu. Znacznie więcej uwagi Sienkiewicz poświęcał oświetleniu prezentowanej w swych utworach rzeczywistości niż jej kolorystyce.

W analizowanej w moim artykule powieści Sienkiewicza można zaobserwować podobne tendencje, jak wcześniej opisane. Pisarz wiele uwagi poświęca zmianom oświetlenia otaczającego świata, chociaż kolory afrykańskiej przyrody (zwłaszcza ożywionej) również przykuwają jego uwagę, co widać szczególnie w odautorskiej narracji. Typowa dla podzwrotnikowej Afryki intensywność kolorów, zwłaszcza w zestawieniu z bardziej stonowanymi barwami

36 Przymiotnik szyfrowy na oznaczenie koloru szarego nie jest notowany w słownikach języka polskiego. 
pustyni czy środkowej Europy, położonej w innej strefie klimatycznej, wywarła zapewne na pisarzu duże wrażenie, chociaż chyba nie tak wielkie, jak tropikalny klimat czy różnice cywilizacyjne i kulturowe. Młodych czytelników, do których kierowana była powieść, mogły jednak zainteresować egzotyczne dla Polaków realia, w tym odmienna od polskiej przyroda, nasycona znacznie bardziej intensywnymi kolorami świata flory i fauny. Jej zatem, a nie jedynie lub przede wszystkim ludziom, poświęcił pisarz wiele uwagi (np. opisy zmieniających się barw pustyni, nieba). W opisach ludzi uwagę powieściowego narratora przyciągnął zwłaszcza kontrast białego koloru skóry Europejczyków oraz czarnego lub brązowego (o różnych odcieniach) Murzynów i Arabów, który został mocno wyeksponowany i powiązany ze zróżnicowaniem rasowym i cywilizacyjnym mieszkańców XIX-wiecznej Afryki.

\section{Bibliografia $^{37}$}

Ampel-Rudolf Mirosława (1994), Kolory. Z badań leksykalnych i sktadniowo-semantycznych języka polskiego, Wydawnictwo Wyższej Szkoły Pedagogicznej, Rzeszów.

Axer Jerzy (2012), Polowanie na wobo z nagonka, w: Wokót „, W pustyni i w puszczy”. W stulecie pierwodruku powieści, red. Jerzy Axer, Tadeusz Bujnicki, Universitas, Kraków, s. 377-389.

Brandys Marian (1995), Śladami Stasia i Nel. Z panem Biegankiem w Abisynii, Świat Książki, Warszawa.

Doroszewski Witold, red. (1966), Stownikjęzyka polskiego, t. VIII, Wiedza Powszechna, Warszawa.

Handke Kwiryna (2002), Świat barw, w: Stownictwo pism Stefana Żeromskiego, t. V, red. Kwiryna Handke, Universitas, Kraków.

Kot Wiesław (2001), W pustyni i w puszczy. Prawda i legenda, G\&P, Poznań.

Krzyżanowski Julian, oprac. (1954), Kalendarz życia i twórczości Henryka Sienkiewicza, w: Henryk Sienkiewicz, Dzieła, t. LVII, red. Julian Krzyżanowski, PIW, Warszawa.

Najder Zdzisław (1956), O „Listach z Afryki” Henryka Sienkiewicza, „Pamiętnik Literacki”, z. 4, s. 333-350.

Ruszała Jadwiga (1995), W krainie egzotyki i przyrody. O „W pustyni $i$ w puszczy” Henryka Sienkiewicza, Wyższa Szkoła Pedagogiczna w Słupsku, Słupsk.

37 Ze względu na bogactwo literatury poświęconej nazwom kolorów w Bibliografii zdecydowano się uwzględnić jedynie te prace, które zostały przywołane w obu częściach artykułu. 
Rychter Joanna (2014), Językowa kreacja barw w poezji Marii Pawlikowskiej-Jasnorzewskiej, Wydawnictwo Naukowe Uniwersytetu Szczecińskiego, Szczecin.

Siedem kolorów Afryki - o podróży po Afryce rozmawiamy z Jolantą Wroną (2014), http://fotowyprawy.com/2011/07/24/siedem-kolorow-afryki-o-podrozy-po-afryce-rozmawiamy-z-jolanta-wrona, [dostęp: 2 lipca 2014].

Siekierska Krystyna (1988a), Barwy przyrody w ,, Trylogii” Henryka Sienkiewicza, „Poradnik Językowy”, z. 5, s. 324-331.

Siekierska Krystyna (1988b), Kolorystyczna charakterystyka postaci ,, Trylogii” Henryka Sienkiewicza, „Poradnik Językowy”, z. 3, s. 177-193.

Siekierska Krystyna (1988c), Nazwy barw w ,, Trylogii” Henryka Sienkiewicza, „Poradnik Językowy", z. 2, s. 106-119.

Sienkiewicz Henryk (1956), Listy z Afryki, PIW, Warszawa.

Sienkiewicz Henryk (2003), W pustyni i w puszczy, Prószyński i S-ka, Warszawa. (Skrót: P)

Tokarski Ryszard (1995), Semantyka barw we współczesnej polszczyźnie, Wydawnictwo UMCS, Lublin.

Widerman Krystyna (1969), Sienkiewicz - kolorysta czy rysownik?, „Poradnik Językowy", z. 9, s. 520-527.

Zaręba Alfred (1954), Nazwy barw w dialektach i historii języka polskiego, Ossolineum, Wrocław.

Maria Borejszo

\section{Colours of Africa in the Novel by Henryk Sienkiewicz W pustyni $i$ w puszczy ("In Desert and Wilderness"). Part II: People and Their Creations}

The object of studies presented in the article are the designations of colours documented in the novel by Henryk Sienkiewicz entitled In Desert and Wilderness. Against all appearances, it is not the issue treated only marginally by the writer, which may be a little surprising if we take into account the character of the book (an adventure novel for youth, focused basically on the lively, attracting attention plot and not on extensive author's narration). The author of the article distinguishes more than a dozen of groups of realities especially often characterised from the point of view of their colours.

Primarily, these are the descriptions concerning the world of African flora and fauna - exotic for the Polish reader. As it results from the conducted studies, the attention of Sienkiewicz is mainly drawn to the colours of animals, especially birds. It is likely that the writer's predilection for hunting played here a decisive role. African flora is basically presented in the form of colourful spots against the background of greenery, and not by detailed descriptions of the appearance of individual representatives of a given species. 
Additionally, the writer's interest is aroused by changes of colours of the sky and the whole surrounding world depending on the time of day, atmospheric conditions, light intensity (mainly sunrises and sunsets).

In the descriptions of people, the narrator pays attention to the differences in the skin colour of the Europeans, Blacks and Arabs. Sienkiewicz devoted less attention to the colours of clothes or ornaments worn by African residents.

The lexis used in the novel, belonging to the field of colours, although semantically quite rich and formally varied, is not very original. There dominate here typical adjectival designations used in their basic meanings, instead of inventive comparisons or metaphors, e.g., biaty (white), czarny (black), czerwony (red), zielony (green), żólty (yellow), niebieski (blue), różowy (pink), szary (grey), srebrny (silver), złoty (gold).

In the studied novel, the field of red has been documented with most examples (e.g., czerwonoskóry (red-skinned), czerwony (red), koralowy (coral), krwawy (bloody), ognisty (fiery), purpurowy (purple), wiśniowy (cherry), zaczerwieniony (reddened); czerwono (red), pasowo (bright red), wiśniowo (cherry); purpura (purple), rubin (ruby); czerwienić się (to become red), zaczerwienić sie (to redden) $)^{38}$, and further on: the field of white (for example: białawy (whitish), biaty (white), pobladty (pale), śnieżny (snowy), wybielony (whitened), zbielaty (bleached); biało (white); pobielenie (whitening); blednać (to become pale), bielić się (to grow white), pobieleć (to become white), poblednać (to grow pale), wybieleć (to grow white), zabielić się (to paint white), zblednać (to turn pale)), the field of blue (for example: błękitnawy (bluish), błękitny (azure), granatowy (navy blue), jasnoniebieski (light blue), niebieski (blue), sinawy (glaucous), siny (livid), siwobłękitny (grey blue); błękitno (blue); błękit (azure); sinieć (to become livid)), the field of green (for example: ciemnozielony (dark green), jasnozielony (bright green), koloru morskiej wody (the colour of sea-water), szarozielony (grey-green), zielonawy (greenish), zielony (green); zielonawo (greeny), zielono (green); zieloność (greenness)), and also the field of black (for example: barwy wegla (the colour of coal), czarny (black), poczerniaty (blackened), sczerniały (turned black); czarno (black); czernieć (to grow black), czernić się (to go black), sczernieć (to grow black)), the field of grey (for example: ptowoszary (tan-grey), popielaty (ash-coloured), stalowy (steel-like), szary (grey), szyfrowy (slate), zielonoszary (green-grey); poszarzeć (to become grey)), the field of brown (for example: brunatny (tawny), kasztanowy (auburn), opalony (suntanned), rudy (ginger), smagty; opalać się (to bronze), opalić się (to get a suntan)), the field of yellow (for example: cynamonowy (cinnamon), płowożólty (buff-yellow), płowy (buff), woskowy (wax), żółty (yellow)), the field of silver (for example: srebrny (silver), srebrzysty (silvery); srebrno

38 This refers to a number of lexemes being a part of a given colour field, i.e. about the wealth of fields, their saturation with lexis, and not the frequency of individual words in the field or the rank of the isolated fields of colour in the entire novel under study. 
(silver); posrebrzeć (to silver-plate), rozsrebrzyć (to become silvery)), the field of pink (for example: różany, różowy; różowo; różowieć), the field of gold (for example: złoty (golden); złoto (gold); złocić się (to show golden)) and the field of violet (for example: lila (lilac), liliowy (lilac); ametyst (amethyst)). In the field of varied colours we can find, among others, such designations as: pregowany (striped), pstry (spotted), siedmiobarwny (seven-coloured), różnobarwny (many-coloured), różnokolorowy (colourfull), drgać odblaskami pawich piór (tremble with reflections of peacock feathers), mienić się jak opale (to shimmer like opals), mienić się jak tęcza (to shimmer like a rainbow), mienić się i grać wszelkimi barwami jak wielkie kwiaty (to glitter and play with all colours like huge flowers), przybrać barwe muszli pertowej (to assume the colour of a pearl conch). Among the general descriptions of colours we can enumerate the adjective kolorowy (colourful) and the expression jaskrawo upierzony (brightly feathered), which can signify both mono-, as well as multi- colours of the realities being described.

In the studied novel, there are quite numerous examples of words from the field signalling different intensity of light, from full brightness to absolute darkness, for instance: blady (pale), blado (pale), blask (radiance), blednać (to grow pale), jasny (bright), rozjaśnić (to light up), światło (light), ciemny (dark), ciemno (dark), ciemność/ciemność tak gęsta, że prawie namacalna (darkness/darkness so thick as almost touchable), ćma (moth), mrok (dimness), pociemnieć (to make dark), ściemnić się (to become dark).

Two adjectives designating colours manifest the greatest frequency, i.e., biaty (white) (106 occurrences in the text) and czarny (black) (58 occurrences), and subsequently according to the frequency of use - the adjectives: czerwony - red (24), różowy - pink (16), zielony - green (13), żótty - yellow (10), płowy - buff (9), szary-grey (9), srebrnysilver (7), niebieski-blue (6), złoty - gold (6), białawy - whitish (5), błękitny - blue (5), purpurowy-purple (5), popielaty-ash-coloured (4).

Additionally, attention should be brought to the designations of colours in less typical forms, e.g., comparisons, metonymy, metaphor. Among the comparative expressions we can find the designations frequently used in Polish, such as: biaty jak kreda/mleko/ papier/śnieg (as white as chalk/milk/paper/snow), czarny jak aksamit/kir/noc (as black as velvet/pall/night), czarno jak w piwnicy (as black as in the cellar), czerwony jak krew (as red as blood), szary jak mysz (as grey as a mouse). Among the designations of colours which are less typical than the ones mentioned above there are collocations such as: drgać odblaskami pawich piór (tremble with reflections of peacock feathers), mieć barwe czystego ametystu (to have the colour of pure amethist), przybrać barwe muszli pertowej (to assume the colour of a pearl conch), mienić sie jak opale (to shimmer like opals), mienić się jak tęcza (to shimmer like a rainbow).

There is definitely more information about the colours of the world depicted in the studied novel by Sienkiewicz than in The Trilogy written by the same author, especially when we take into account the differences in length of the analysed writings. In the novel 
In Desert and Wilderness there dominate the descriptions of colours of nature-which is exotic for Polish readers - rather than people, which results, among others, in greater frequency of designations from the colour field ascribed to African flora (green and pink) if we compare it with The Trilogy.

Keywords: Henryk Sienkiewicz; 19th-century Polish novel; Africa; colours; semantic and lexical fields; names of colours.

prof. dr hab. Maria Borejszo - Pracownia Leksykologii, Instytut Filologii Polskiej Uniwersytetu im. Adama Mickiewicza w Poznaniu; zainteresowania naukowe: historia języka polskiego (głównie dzieje słownictwa), język religijny, język pisarzy, struktura i język wybranych tekstów użytkowych. 
